економічної стійкості в системі основних економічних характеристик підприємства, проаналізовано процес управління економічною стійкістю підприємства, розглянуті основні принципи забезпечення стійкості підприємства.

\section{СПИСОК ЛІТЕРАТУРИ}

1. Баканова. М. Н. Аналіз основних чинників економічної стійкості сучасного підприємства / М. Н. Баканова - М: 2003 - №2 216-222 c.

2. Єгоршин. А. П. Концепція управління інноваційним розвитком / А. П. Сгоршин - Новгород: НІМБ, 2006. $-75 \mathrm{c}$.

3. Мансуров. Н. Е. Підвищення економічної конкурентоспроможності енергетичних підприємств на основі технічного переозброєння / Н. Е. Мансуров Новгород, 2004. - $160 \mathrm{c}$.

4. Пітер Ф. Друкер Ефективний керівник / Друкер Пітер Ф. - М: «Вільямс», 2007. - 224 с.
5. Афонін В. В. Інноваційний менеджмент та економічна оцінка реальних інвестицій: [навч. посібник] / В. В. Афонін - М: Гардаріки, 2006. - 86 с.

6. Артеменко В. Р., Беллендир М. В. Фінансовий аналіз : [навч. посібник] / В. Р. Артеменко, М. В. Беллендир - М: «ДИС», 2007. - 203 с.

7. Луссе А. В. Макроекономічна рівновага та стійкість економічного розвитку. / А. В. Луссе - СПб: Спбгуеф, 2011. - 342 с.

8. Трофілова А. А. Оцінка ефективності інноваційного розвитку підприємства. / А. А. Трофілова. - М: Фінанси і статистика, 2005. - 340 с.

9. Абалкин Л. В., Аксьонов В. В., Алтухов Ю. П. Нова парадигма сталого розвитку, комплексні дослідження проблем сталого розвитку. / Л. В. Абалкин, В. В. Аксьонов, Ю. П. Алтухов. - М: Академія, 2010. - 458 с.

10. Камаєв В. Д. Економіка та бізнес. / В. Д. Камаєв. - М: Економіка, 2013. - 237 с.

11. Балабанов I. T. Фінансовий менеджмент. / I. Т. Балабанов. - М: Фінанси і статистика. 2011. - 224 c.

Рецензент д.е.н., професор УІПА Прохорова В.В. Експерт редакційної колегії к.е.н., дочент УкрДАЗТ Уткіна Ю.М.

УДК 330.322.214

\title{
ПІДВИЩЕННЯ ЕФЕКТИВНОСТІ ОЦІКИ РЕЗУЛЬТАТІВ ДІЯЛЬНОСТІ ПЕРСОНАЛУ
}

\author{
Янченко Н.В., к.е.н., доцент, \\ Роза А.А., студент (ХНУБА)
}

Актуальність вивчення питань, пов'язаних з оиінкою результатів діяльності персоналу на підприємствах різних галузей, обумовлена інтересом до вирішення проблеми підвищення ефективності управління персоналом, яке все більше стає визначальним фактором конкурентоспроможності будьякого підприємства. Кожна організаиія прагне зберегти найліпші кадри, створити їм умови для професійно-кваліфікаційного зростання $i$ одночасно позбутися прачівників інертних, малокваліфікованих, безперспективних.

Ключові слова: оцінка, персонал, управління персоналом, ефективність, методи.

\section{ПОВЫШЕНИЕ ЭФФЕКТИВНОСТИ ОЦЕНКИ РЕЗУЛЬТАТОВ ДЕЯТЕЛЬНОСТИ ПЕРСОНАЛА}

\author{
Янченко Н.В., к.э.н., доцент, \\ Роза А.А., студент (ХНУБА)
}

Актуальность изучения вопросов, связанных с оченкой результатов деятельности персонала на предприятиях различных отраслей, обусловлена интересом к решению проблемы повышения эффективности управления персоналом, которое все больше становится определяющим фактором конкурентоспособности любого предприятия. Каждая организация стремится сохранить наилучшие кадры, создать им условия для профессионально-квалификационного роста и одновременно избавиться работников инертных, малоквалифицированных, бесперспективных.

Ключевые слова: оценка, персонал, управление персоналом, эффективность, методы. 


\title{
ENHANCE THE EVALUATION OF STAFF PERFORMANCE
}

\author{
Yanchenko N.V., Ken, associate Professor, \\ Rosa A.A., student (HOBA)
}

Evaluation of staff is one of the most important components of the personnel management system. The relevance of the study of issues related to the assessment of the performance of staff in enterprises of different industries, due to the interest in solving the problem of improving the management of personnel, which is increasingly becoming a determining factor in the competitiveness of any company. Every organization strives to maintain the best possible footage, to create conditions for the professional qualification of growth and at the same time get rid of employees inert, low-skilled, unpromising.

The essence of the problem and assessment personnel must be available and understandable to employees as part of the main production and management personnel.

The ultimate goal should be to use ratings staffing company knowledgeable staff and increase efficiency.

Keywords: evaluation, personnel, personnel management, efficiency, methods.

Постановка проблеми. Для досягнення результатів у сфері діяльності персоналу на підприємствах важливо не тільки представляти та контролювати роботу з кадрами, але та шукати нові шляхи для іiї поліпшення. Для досягнення цієї мети призначена система оцінки персоналу, покликана визначити, наскільки конкретний співробітник або персонал організації в цілому успішний і наскільки ефективно виконує свої обов'язки.

Аналіз останніх наукових досліджень $\boldsymbol{i}$ публікацій. Аналіз публікацій 3 економіки підприємства та менеджменту показав, що питання ефективності діяльності персоналу, такі як підбір, розміщення, перепідготовка кадрів, навчання, підготовка керівників, мотивація до праці, а також аналіз трудових процесів $є$ предметом наукових досліджень. Однак багато проблем, пов'язані 3 ефективністю керування персоналом, не можна визнати досить розробленими.

У цей час немає єдиного підходу до оцінки ефективності системи керування персоналом. Це пов'язане 3 тим, що саме поняття такої системи з'явилося недавно, а також 3 складністю та багатоаспектністю проблеми. Відсутність обгрунтованої концепції оцінки ефективності керування персоналом робить проблему актуальної.

Теоретико-методологічні, методичні питання керування персоналом на підприємстві та підвищення ефективності його діяльності були та залишаються предметом постійних наукових досліджень. Проблеми ефективності керування персоналом розглядаються вітчизняними вченими Балабановою Л.В.[1], Головатим М.Ф.[2], Лукашевичем М.П. [2], Дмитренко Г.А. [2], Данюк В. М. [3], Завіновська Г.Т.[4], Кириченко О.А.[5], Колот А.М.[6] та інші.

Метою роботи є теоретико-методичне обгрунтування, а також розробка практичних рекомендацій 3 удосконалювання оцінки ефективності керування персоналом на підприємстві.

Виклад основного

\section{досліджсення.}

Оцінювання персоналу - досить складна як в методичному, так i в організаційному плані робота. Перш за все, потрібно відмітити, що єдиної універсальної методики, придатної для вирішення всього комплексу завдань, які ставляться до оцінки персоналу, просто не існує. Поки що загальноприйнятої методики оцінки персоналу немає як у зарубіжній, так і у вітчизняній практиці. Яке визначення оцінювання персоналу дають видатні вченні надано у таблиці 1.

Перехід на ринкові відносини, ускладнення економічних зв'язків, науково-технічний прогрес, а також інтенсивний розвиток продуктивних сил приводить до необхідності зміни методів праці, що вимагає більше злагодженої структури управлінських органів, діяльність яких спрямована на підвищення ефективності керування персоналом підприємства [11]. Однак, для того, щоб визначити наскільки ефективна система керування персоналом, необхідно адаптувати наявні або виробити нові методики для оцінки ефективності керування персоналом. Оцінку ефективності керування персоналом можна визначити як систематичний, формалізований процес, спрямований на вимір витрат і вигід, пов'язаних із програмами діяльності керування персоналом для співвіднесення їхніх результатів 3 підсумками базового періоду та цілями підприємства.

Система оцінки ефективності керування персоналом на підприємстві заснована на інформації про працівників: показники продуктивності, кваліфікаційні, професійні, вікові характеристики, просування по службі, новаторська активність, а також медичні та психологічні параметри.

У цей час на багатьох підприємствах оцінка ефективності керування персоналом містить у собі такі напрямки, виражені в об'єктивних показниках розвитку виробництва [12]:

1) визначення кількісної, структурної i якісної укомплектованості кадрового складу; 
2) показники ступеня задоволеності працівників роботою в організації, особливо, якщо робота 3 персоналом будувалася на обліку соціальних моментів у трудових відносинах (тут ефект може виявитися в підвищенні продуктивності праці, зменшенні збитку від плинності кадрів у зв'язку зі стабілізацією колективу);
3) визначення показників відносної економії засобів при скороченні строків навчання завдяки підбору професійно орієнтованих працівників;

4) установлення тенденцій збільшення випуску продукції внаслідок росту продуктивності праці, підвищення іiї якості, сортності.

Таблиия 1

Аналіз визначення терміну «оиінювання персоналу» вітчизняними вченими

\begin{tabular}{|c|c|c|}
\hline $\begin{array}{l}\text { № } \\
3 / \Pi\end{array}$ & Джерело & Визначення \\
\hline 1 & 2 & 3 \\
\hline 1 & Балабанова Л.В. & $\begin{array}{l}\text { Оцінювання персоналу - це цілеспрямований процес встановлення відповідності } \\
\text { якісних характеристик персоналу (здібностей, властивостей) вимогам посади або } \\
\text { робочого місця [1]. }\end{array}$ \\
\hline 2 & $\begin{array}{lrr}\text { Головатий } & \text { М. } & \text { Ф., } \\
\text { Лукашевич } & \text { М. } & \text { П., } \\
\text { Дмитренко Г. А. } & \end{array}$ & $\begin{array}{l}\text { Під оцінюванням персоналу розуміють процедуру, за допомогою якої виявляється } \\
\text { ступінь відповідності якостей працівника, його трудової поведінки, результатів } \\
\text { діяльності певним вимогам }[2,3] \text {. }\end{array}$ \\
\hline 3 & Завіновська Г.Т. & $\begin{array}{l}\text { Оцінювання персоналу - це запланована, формалізована характеристика трудової } \\
\text { діяльності зайнятих, ефективності роботи персоналу [4]. }\end{array}$ \\
\hline 4 & Кириченко О. А. & $\begin{array}{l}\text { Оцінювання персоналу використовується для визначення відповідності працівника } \\
\text { вакантному чи робочому місцю (посаді), яке він у даний час займає [5]. }\end{array}$ \\
\hline 5 & Колот А.М. & $\begin{array}{l}\text { Оцінка персоналу полягає у визначенні того, якою мірою кожний працівник досягає } \\
\text { очікуваних результатів праці й відповідає тим вимогам, які випливають } 3 \text { його } \\
\text { виробничих завдань [6]. }\end{array}$ \\
\hline 6 & Савченко В. А. & $\begin{array}{l}\text { Оцінювання персоналу є процедура, що здійснюється з метою виявлення ступеня } \\
\text { відповідності професійних, ділових та особистих якостей працівника, кількісних і } \\
\text { якісних результатів його трудової діяльності визначеним вимогам [7]. }\end{array}$ \\
\hline 7 & $\begin{array}{l}\text { Скопилатов } \\
\text { Єфремов О.Ю. }\end{array}$ & $\begin{array}{l}\text { Ділова оцінка персоналу - це компонент діагностики персоналу, цілеспрямований } \\
\text { процес встановлення відповідності кількісних і якісних професійних характеристик } \\
\text { персоналу вимогам посади (робочого місця), підрозділи і організації в цілому [8]. }\end{array}$ \\
\hline 8 & Федулова Л.І. & $\begin{array}{l}\text { Під діловою оцінкою персоналу розуміється цілеспрямований процес встановлення } \\
\text { відповідності якісних характеристик персоналу вимогам посади й робочого місця [9]. }\end{array}$ \\
\hline 9 & Шегда А.В. & $\begin{array}{l}\text { Оцінювання персоналу визначає рівень кваліфікації працівників, рівень знань, } \\
\text { навичок, здібностей, дає уявлення про ділові та моральні риси особистості [10]. }\end{array}$ \\
\hline
\end{tabular}

Проведення оцінки ефективності керування персоналом на підприємстві дозволить:

1) поліпшити функціонування керування персоналом через забезпечення їхніми засобами рішення питань про те, коли необхідно припинити, а коли підсилити яку-небудь діяльність;

2) визначити реакцію з боку менеджерів нижчої ланки на ефективність керування персоналом;

3) допомогти керуванню персоналом вносити свій внесок у досягнення цілей підприємства.

Методи оцінки ефективності керування персоналом ділять на три групи [6]: кількісні, якісні (або описові) і комбіновані (або проміжні)

Найбільше поширення одержали кількісні методи: бальний, коефіциєнтний i бальнокоефіциєнтний. Їхніми перевагами $є$ об'єктивність, незалежність особистого відношення експертів до фахівця, можливості формалізації результатів, порівняння параметрів, систематизації результатів і використання математичних методів (див.табл.2).
Кожна оцінка ділових якостей має чотири рівні виявлення й оцінюється в балах: низький - 0,5 , середній - 1, вище середнього - 2, високий - 3 бали. Оцінка від 0,5 до 3 балів встановлюється робітникові за кожною 3 ознак 3 врахуванням іiі питомого значення.

Оцінка всієї сукупності ділових якостей визначається підсумком оцінок рівнів ознак 3 врахуванням їх питомої значимості.

Оцінка складності функцій, які виконують робітники.

Оцінка складності функцій, виконуваних робітниками, проводиться за ознаками, врахованими в тарифно-кваліфікаційному довіднику й відображеними в тарифному розряді, а також беруться до уваги не включені в довідник ознаки, але такі, що впливають на складність праці робітників i вимагають від них більшого напруження, досвіду, зусиль, а саме: різноманітність робіт, керівництво ланкою, бригадою, додаткова відповідальність у технологічному процесі, робота на основі 
самоконтролю.

Оцінка результатів праці робітників враховує кількісні та якісні параметри робіт, що виконуються, а також їхню ритмічність. Згідно 3 методичними рекомендаціями, ознаками та ціною прийнято наступні бальні оцінки (див.табл.3).

Таблиия 2

Бальні оиінки характеристик ділових якостей робітника

\begin{tabular}{|c|c|c|c|c|c|c|}
\hline \multirow[t]{2}{*}{$\begin{array}{l}\text { № } \\
\text { 3/ח }\end{array}$} & \multirow[t]{2}{*}{ Характеристика (ознаки, риси) } & \multirow{2}{*}{$\begin{array}{c}\text { Питома } \\
\text { значи-мість } \\
\text { у частках } \\
\text { одиниці }\end{array}$} & \multicolumn{4}{|c|}{$\begin{array}{c}\text { Оцінка рівнів ознак з врахуванням їх } \\
\text { питомої ваги, балів }\end{array}$} \\
\hline & & & 0,5 & 1,0 & 2,0 & 3,0 \\
\hline 1 & 2 & 3 & 4 & 5 & 6 & 7 \\
\hline 1 & Професійна компетентність & 0,17 & 0,08 & 0,17 & 0,34 & 0,51 \\
\hline 2 & $\begin{array}{l}\text { Виявляє } \quad \text { винахідливість } \\
\text { ініціативність у роботі }\end{array}$ & 0,15 & 0,08 & 0,15 & 0,30 & 0,45 \\
\hline 3 & $\begin{array}{l}\text { Добре виконує роботу (без нагадувань, } \\
\text { примусу) не допускає без, діяльності }\end{array}$ & 0,14 & 0,07 & 0,14 & 0,28 & 0,42 \\
\hline 4 & $\begin{array}{l}\text { Точно виконує всі доручення, } \\
\text { відповідальний }\end{array}$ & 0,13 & 0,06 & 0,13 & 0,26 & 0,39 \\
\hline 5 & $\begin{array}{l}\text { Вміє ефективно працювати в колективі } \\
\text { допомагає іншим його членам, колегам }\end{array}$ & 0,15 & 0,08 & 0,15 & 0,30 & 0,49 \\
\hline 6 & $\begin{array}{lrrr}\text { Сприймає зміни } & \text { на } & \text { виробництві, } \\
\text { виявляє здатність } & \text { до } & \text { неординарних } \\
\text { рішень і нових ідей } & & \end{array}$ & 0,15 & 0,08 & 0,15 & 0,30 & 0,43 \\
\hline 7 & Емоційно-витриманий & 0,11 & 005 & 0,11 & 0,22 & 0,33 \\
\hline
\end{tabular}

Таблиия 3

Бальні оцінки ознак, щео визначають результати пращчі робітників

\begin{tabular}{|c|c|c|c|c|c|}
\hline & \multirow[t]{2}{*}{ Назва ознаки } & \multirow{2}{*}{$\begin{array}{c}\text { Питома } \\
\text { значимість (в } \\
\text { частках одиниці) }\end{array}$} & \multicolumn{3}{|c|}{$\begin{array}{c}\text { Оцінка рівнів ознак з врахуванням питомої } \\
\text { значимості, балів }\end{array}$} \\
\hline & & & 1 & 2 & 3 \\
\hline 1 & Обсяг виконаних робіт & 0,40 & 0,40 & 0,80 & 1,20 \\
\hline 2 & Якість виконаних робіт & 0,40 & 0,40 & 0,80 & 1,20 \\
\hline 3 & Ритмічність & 0,20 & 0,20 & 0,40 & 0,80 \\
\hline
\end{tabular}

Використовуючи в сукупності одержані результати за всіма напрямками, можна здійснити комплексну оцінку працівника та його роботи. Результати оцінки повинні враховуватись у процесі переміщення кадрів. Тут необхідно дотримуватись відповідності результатів оцінок відносно підвищення чи пониження працівників на посаді, кваліфікаційному розряду, а також 3 врахуванням їх інтересів, здібностей i можливостей.

Суть і завдання оцінки персоналу мають бути доступними i зрозумілими основному складу працівників як виробничого, так i управлінського персоналу.

Кінцевою метою використання оцінок повинно бути укомплектування підприємства висококваліфікованим персоналом та підвищення ефективності його роботи.

Вивчення публікацій дозволило сформулювати основні напрямки підвищення ефективності використання кадрів на підприємстві за рахунок удосконалювання системи оцінки ефективності керування персоналом. Вона повинна здійснюватися комплексно, з урахуванням факторів виробництва.

Продуктивність праці $\epsilon$ основним показником використання персоналу та характеризує прибутковість виробництва.

Таким чином, для вдосконалювання оцінки ефективності керування персоналом необхідне проведення таких заходів [7]:

1. Планування та прогнозування персоналу: провести аналіз кадрового потенціалу, ринку праці, планування та прогнозування потреби в персоналі, оцінку кандидатів на вакантну посаду, установити взаємозв'язок із зовнішніми джерелами, що забезпечують кадрами організацію.

2. Оформлення та облік кадрів: оформлення та облік прийому, звільнень, переміщень, інформаційне забезпечення системи керування персоналом, профорієнтація, забезпечення зайнятості. 
3. Аналіз і розвиток засобів стимулювання праці: керування трудовою мотивацією, розробка систем оплати праці, використання засобів морального заохочення, розробка форм участі в прибутках і капіталі, створення “корпоративного духу".

4. Умови праці: дотримання вимог психофізіології праці, ергономіки праці, технічної естетики, охорона праці та техніка безпеки, охорона навколишнього середовища, вартісна оцінка втрат робочого часу.

5. Розробка оргструктур керування: аналіз сформованої оргструктури керування, проектування та побудова нової оргструктури керування, розробка штатного розкладу.

6. Розвиток персоналу: технічне та економічне навчання, перепідготовка та підвищення кваліфікації, робота 3 кадровим резервом, службове та професійне просування, професійна та соціально-психологічна адаптація нових працівників.

7. Трудові відносини: аналіз і регулювання групових i особистісних взаємин, керування виробничими конфліктами та стресами, соціальнопсихологічна діагностика, дотримання етичних норм взаємин.

8. Розвиток соціальної інфраструктури: організація громадського харчування, керування житло-побутовим обслуговуванням, розвиток культури та фізичного виховання, забезпечення охорони здоров'я та відпочинку.

Висновки. Створення системи оцінки ефективності керування персоналом є невід'ємною умовою успішного керування трудовими ресурсами організації, що у свою чергу забезпечує ефективну економічну діяльність підприємства. Сьогодні механізм оцінки керування персоналом $€$ недостатньо розробленим. Безумовно, система показників, необхідних для визначення ефективності керування, має потребу в доробці. Рішення цього завдання дозволить об'єктивно оцінювати ефективність організаційних і соціальних заходів, уточнювати завдання та мети. Таким чином, удосконалювання оцінки ефективності як системи процедур стане засобом, що допомагає оцінити якість системи керування персоналом і відповідно підвищить результативність роботи підприємства. У даній роботі отримала подальший розвиток система оцінки персоналу організації, як системи процедур. Використання на практиці запропонованої оцінки позитивно вплине на підвищення рівня економічної ефективності організації. Також обгрунтовано проведення яких заходів необхідно для вдосконалювання оцінки ефективності керування. Зокрема, запропоновано оцінку здійснюватися комплексно, 3 урахуванням факторів виробництва. Запропоновано методичний підхід до визначення показників, що дало змогу визначити перелік існуючих проблем та надати обгрунтовані пропозиції щодо впровадження корегуючих та/чи превентивних заходів, спрямованих на підвищення ефективності управління персоналом.

\section{СПИСОК ЛИТЕРАТУРЫ}

1. Балабанова Л.В. Управління персоналом: Навч. посібник / Л.В. Балабанова, О.В. Сардак. - К.: Професіонал, 2006. - 512 с.

2. Головатий М. Ф. Управлінські аспекти соціальної роботи. Курс лекцій / М. Ф. Головатий , М. П. Лукашевич, Г. А. Дмитренко та ін. - К.: МАУП, 2004. - 368 c

3. Данюк В. М. Менеджмент персоналу: Навч. посіб. / В. М. Данюк, В. М. Петюх, С. О. Цимбалюк та ін.; За заг. ред. В. М. Данюка, В. М. Петюха. - К.:КНЕУ, 2004. - 398 c.

4. Завіновська Г. Т. Економіка праці: навч. посіб. / Г. Т. Завіновська. - К.: КНЕУ, 2003. - 432 с.

5. Кириченко О.А. Менеджмент зовнішньоекономічної діяльності: Навч. посіб./ О.А. Кириченко/ - 3-тє вид., перероб. і доп. - К.: ЗнанняПрес, 2002. - 384 c.

6. Колот А.М. Мотивація персоналу: Підручник. / А.М. Колот - К.: КНЕУ, 2002 - 337 с.

7. Савченко В. А. Управління розвитком персоналу : навч. посіб. / В. А. Савченко. - Київ : КНЕУ,2002. - $351 \mathrm{c}$.

8. Скопылатов, И.А. Управление персоналом / И.А. Скопылатов, О.Ю. Ефремов. - СПб.: Изд-во Смольного университета, 2000. - 400с.

9. Федулова Л. І. Менеджмент організацій: Підручник/ Л. І. Федулова, І. В. Сокирник, В. В. Стадник, М. А. Йохна, О.С. Новикова, С. Г. Рясних. К.: Либідь, 2004. - 448 с.

10. Полуянов В.П., Воробьева И.С. Совершенствание оценки эффективности управления персоналом. Вісник Хмельницького національного університету. Т.3. Економічні науки. - 2009. - №6. C. $188-191$.

11. Татулов Б. Э. Проблемы оценки эффективности управления персоналом [Електронный ресурс] / Б. Э. Татулов. - Режим доступа: http:

www.cfin.ru/bandurin/article/sbm05/21.shtml.

12. Петрович Й. М. Економіка підприємства: Підручник / Й. М. Петрович. - 2-ге вид., виправл. Львів : "Магнолія плюс", видавець СПД ФО В. М. Піча. - 2006.

Рещензент д.е.н., професор ХНУБА Іванілов О.С. Експерт редакційної колегії к.е.н., дочент УкрДАЗТ Уткіна Ю.М. 